\title{
Combination of Ozonation and Adsorption Using Granular Activated Carbon (GAC) for Tofu Industry Wastewater Treatment
}

\author{
Eva Fathul Karamah`, Ika Putri Adripratiwi, and Linggar Anindita \\ Department of Chemical Engineering, Universitas Indonesia, Kampus UI, Depok 16424, Indonesia
}

Received July 18, 2017; Accepted May 3, 2018

\begin{abstract}
Tofu industry wastewater is one of the environmental pollutants that need more effective treatment. Ozonation and adsorption method is known to have the capability to oxidize organic compound in wastewater. Adsorption is done by using Granular Activated Carbon (GAC) as an adsorbent to increase tofu wastewater degradation process by adsorbing organic materials and increasing production of hydroxyl radical as the main oxidizing agent. This research is carried out to evaluate the performance of ozonation, adsorption, and combination of both in processing tofu wastewater. To evaluate the significance of ozone dosage and amount of GAC used, these variations are varied which are 60, 111, and $155 \mathrm{mg} / \mathrm{h}$ of ozone dosage and 50, 75, and $100 \mathrm{~g}$ of the amount of GAC used. Parameters of the process are organic substances of tofu wastewater such as Chemical Oxygen Demand (COD), Total Suspended Solid (TSS), and $\mathrm{pH}$. The measurements are being done using a spectrophotometer, colorimeter, and $\mathrm{pH}$ meter. The outcome of this research is to provide an alternative method in the liquid waste treatment of the tofu industry and the processed wastewater to meet the environmental quality standards. The more ozone and the more quantity of GAC used, the higher the quantity of hydroxyl radicals formed. Addition of GAC in the ozonation process results in more than $100 \%$ increase in hydroxyl radical production. Combination of ozonation and adsorption is able to remove $377.12 \mathrm{mg} / \mathrm{L}$ of COD and $26 \mathrm{mg} / \mathrm{L}$ of TSS.
\end{abstract}

Keywords: chemical oxygen demand; granular activated carbon; ozone; tofu wastewater; total suspended solid

\section{ABSTRAK}

Limbah cair industri tahu merupakan salah satu pencemar lingkungan yang membutuhkan proses pengolahan yang lebih efektif. Metode ozonasi dan adsorpsi telah diketahui dapat mengoksidasi senyawa organik di dalam air. Proses adsorpsi dilakukan dengan menggunakan Granular Activated Carbon (GAC) sebagai adsorben untuk meningkatkan efektivitas proses degradasi limbah cair tahu dengan cara mengadsorpsi material organik dan meningkatkan produksi radikal hidroksil, agen oksidator utama. Penelitian ini dilakukan untuk mengevaluasi performa ozonasi, adosrpsi, dan kombinasi keduanya dalam degradasi limbah cair tahu. Untuk mengevaluasi seberapa signifikan pengaruh dosis ozon dan jumlah GAC yang digunakan, kedua parameter ini divariasikan yaitu menggunakan 60, 111, and $155 \mathrm{mg} / \mathrm{jam}$ ozon dan 50, 75, dan $100 \mathrm{~g}$ GAC yang digunakan. Paramater dari penelitian ini adalah jumlah senyawa organik dalam bentuk Chemical Oxygen Demand (COD), Total Suspended Solid (TSS), dan $\mathrm{pH}$ di dalam limbah cair tahu. Pengukuran parameter-parameter ini menggunakan spektrofotometer, kolorimeter, dan $\mathrm{pH}$ meter. Luaran dari penelitian ini diharapkan dapat memberikan metode alternative dalam pengolahan limbah cair industri tahu agar dapat memenuhi standar baku mutu lingkungan. Makin banyak ozon dan GAC yang digunakan, makin besar jumlah radikal $\mathrm{OH}$ yang dihasilkan. Penambahan GAC pada proses ozonasi meningkatkan jumlah radikal $\mathrm{OH}$ yang dihasilkan hingga lebih dari 100\%. Kombinasi ozonasi dan adsorpsi dapat menurunkan COD hingga $377,12 \mathrm{mg} / \mathrm{L}$ dan TSS $26 \mathrm{mg} / \mathrm{L}$.

Kata Kunci: chemical oxygen demand; granular activated carbon; limbah cair tahu; ozon; total suspended solid

\section{INTRODUCTION}

Production process in tofu industry yields wastes in form of liquid and solid. The liquid waste is produced by washing, boiling, pressing, and molding process. Tofu liquid wastewater contains a high amount of organic content and is damaging to the environment [1]. For every kilogram of soybean used, the amount of water required for processing is $45 \mathrm{~L}$ and it will yield $43.5 \mathrm{~L}$ of liquid waste [2]. Normally, liquid wastewater of tofu industry has Biological Oxygen Demand (BOD) of 5.000-10.000 mg/L, Chemical Oxygen Demand (COD) of $7.000-12.000 \mathrm{mg} / \mathrm{L}$, Total Suspended Solid (TSS) of $6.000-8.000 \mathrm{mg} / \mathrm{L}$, and $\mathrm{pH}$ around 4-5 [3]. According to

* Corresponding author. Tel : +62-81284363908

DOI: $10.22146 / \mathrm{ijc} .26724$

Email address : eva@che.ui.ac.id

Eva Fathul Karamah et al. 
Indonesian Ministry of Environment and Forestry Decree No. 5 the Year 2014 [4], the maximum number of BOD, COD, and TSS are 150, 300, and $200 \mathrm{mg} / \mathrm{L}$ respectively, with $\mathrm{pH}$ around 6 to 9 . COD is the amount of oxygen needed to oxidize soluble and particulate organic matter in water. TSS is a measure of the mass of fine inorganic particles suspended in the water.

Ozone is known for having the ability to oxidize complex organic molecule into more simple forms and can increase the biodegradability of wastewater, resulting in lower toxicity level of the organic substances [5]. Ozone will react with substances in water by two different mechanisms, namely direct and indirect reaction. The direct reaction is a selective reaction of ozone with the substance, while the indirect reaction of ozone involved the usage of radical ions such as hydroxyl radical [6].

Adsorption of organic substances using activated carbon is an effective method because activated carbon has a large pore size and wide internal surface area [7]. Adsorption of organic substances into activated carbon consists of three mechanisms, namely mass transfer from a liquid into carbon particle, mass transfer or diffusion in the pore, and surface reaction [8].

Despite being a strong oxidizing agent, ozone is quite selective. Hydroxyl radical ( $\mathrm{HO} \cdot)$ is not as selective as ozone. Advanced Oxidation Process (AOP) is a method of liquid oxidation based on the production and usage of hydroxyl radical to oxidize certain substances. Hydroxyl radical has oxidation potential value of $2.80 \mathrm{eV}$, which is higher than ozone itself that only has a potential value of $2.07 \mathrm{eV}$. Therefore, hydroxyl radical is preferred to oxidize organic substances that are hard to degrade [9]. Combination of ozonation with adsorption method usually called by catalytic ozonation - using Granular Activated Carbon (GAC) provide a strong synergy in terms of degradation of harmful substances in liquid wastewater. The presence of GAC will increase the acceleration rate of ozone decomposition into hydroxyl radical or other radical substances. Other than that, the GAC also facilitates the adsorption and reaction of organic compounds with ozone on its surface, thereby, increasing the degradation of organic compounds [10]. On the other hand, the saturated time of GAC is prolonged and frequent regeneration is not required [11].

There have been many studies reporting on the use of the combination method of ozone and adsorption using activated carbon to degrade pollutant compounds in wastewater. However, most of these studies use a synthetic waste solution. Only a few of them applied for industrial wastewater, and none of them applied for tofu industry wastewater. Gümüș and Akbal [12], compared three methods: ozonation $\left(\mathrm{O}_{3}\right)$, iron coated zeolite catalyzed ozonation $\left(\mathrm{ICZ}-\mathrm{O}_{3}\right)$ and granular activated carbon catalyzed ozonation $\left(\mathrm{GAC}-\mathrm{O}_{3}\right)$ for removal of humic acid from an aqueous solution. They found that the use of ICZ or GAC as a catalyst increased the decomposition of humic acid compared to single ozonation. Karamah et al. [13], treated synthetic wastewater containing phenol using a combination method of ozonation-adsorption with GAC in a packed bed rotating reactor. The result shows that the combination method generated more hydroxyl radicals compared with single ozonation and single adsorption, which further enhances the ability of phenol degradation in solution. Rozas et al. [14], studied the removal of organic micropollutants (OMPs) by ozone and the combination of ozone and powdered activated carbon. The addition of PAC slightly increases the oxidation rate of OMPs mixture in natural water. However, the presence of PAC gave a rapid TOC decrease compare to single ozonation. One of a few studies reported the application of a combined method of ozonation and activated carbon adsorption [15] that was for the removal of COD and cyanide ions from synthetic waste containing COD and cyanide ions and wastewater from the tapioca starch industry. She found that combined process of ozonation and GAC adsorption is more effective in cyanide and COD removal process than single ozonation and single adsorption method because GAC can either adsorb cyanide and COD and also increase $\cdot \mathrm{OH}$ generated in ozonation process.

This study aims to investigate the combined method of ozonation and GAC adsorption in the treatment of tofu industry wastewater, and to compare it with corresponding singular methods in order to assess the significance of the combination. The effect of certain parameters namely ozone dosage and the amount of GAC used are evaluated on the performance of the process in the form of COD and TSS removal and the change of the $\mathrm{pH}$ solution.

\section{EXPERIMENTAL SECTION}

\section{Materials}

The materials that were used in this research consist of tofu liquid wastewater taken from a tofu production factory in South Jakarta, ozone, and Granular Activated Carbon (GAC), distilled water, ozone indigo reagent ( $\mathrm{HACH}$ cat. 2518025), potassium iodide (Merck, p.a.), sodium thiosulfate (Merck, p.a.), sulphuric acid (Merck, p.a.), potassium permanganate (Merck, p.a.), COD reagent ( $\mathrm{HACH}$ cat. 2125925), and starch indicator.

\section{Instrumentation}

Instrumentations used for performing this experiment are Packed Bed Reactors (PBR), commercial household appliance Ozonator (X-Troy and 
Hanaco), venturi injector (Mazzei), diaphragm pump, wastewater reservoir, hose, stirrer (IKA), magnetic bar, beaker glass, volumetric flask, Erlenmeyer, burette, analytical weight (Sartorius), pipette, spatula, desiccator, stopwatch, heating block digester (DRB 200), UltravioletVisible spectrophotometer (BEL UV-MS1 single beam), colorimeter (HACH DR890), test tube, spectrophotometer vial, and $\mathrm{pH}$ meter (eco tester). Scheme of instrumentations used for performing this experiment is shown in Fig. 1.

\section{Procedure}

\section{Hydroxyl radical quantification test}

This test is carried out to know the amount of hydroxyl radical produced for the configuration method where ozone is present in the system. Solution used in this test is distilled water which $\mathrm{pH}$ is altered around the actual $\mathrm{pH}$ of tofu liquid wastewater using sulphuric acid. For each configuration method, samples are taken at minute $15,30,45$, and 60 . Ten milliliters of sample is put into an Erlenmeyer. Then, $\mathrm{H}_{2} \mathrm{SO}_{4}$ is added to the solution. The sample is titrated with potassium permanganate $\left(\mathrm{KMnO}_{4}\right)$ until the color of the sample changed from transparent to slightly pink. The amount of titrant used is noted.

\section{Granular activated carbon preparation}

GAC used for this experiment is washed using distilled water and sucked using a vacuum pump until there is no more suspension left in the water. GAC is then heated in the oven at temperature $110^{\circ} \mathrm{C}$ for $3 \mathrm{~h}$. To get the surface area of the GAC, test using BET Surface Autosorb is being done.

\section{Tofu liquid wastewater preparation}

Tofu liquid wastewater is filtrated first using filter cloth 400 mesh. Because tofu liquid wastewater produced foam when being circulated in the system, dilution with distilled water was done.

\section{Ozonation method for tofu liquid wastewater treatment}

Five liters of tofu liquid waste and distilled water mixture is put into the reservoir. The tofu liquid waste is pumped into the reactor using a diaphragm pump. Ozone is injected into the system by connecting the hose from Ozonator to the reactor using venture injector. This method was operated for 1 hour, and samples are taken every $15 \mathrm{~min}$. This whole process is done for configuration of one, two, and three ozone dosages; 62, 111, and $155 \mathrm{mg} / \mathrm{h}$.

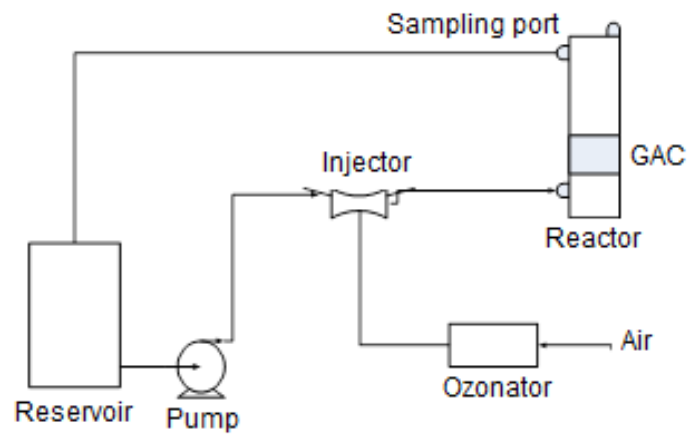

Fig 1. Scheme of experimental instrumentation

\section{Adsorption with GAC method for tofu liquid wastewater treatment}

Five liters of tofu liquid waste and distilled water mixture is put into the reservoir. The tofu liquid waste is pumped into the reactor using a diaphragm pump. GAC is placed in the inside of the reactor. This method is whole process was done for configuration of 50,75 , and $100 \mathrm{~g}$ of GAC used.

\section{Combination of ozonation and adsorption with GAC for tofu liquid wastewater treatment}

Five liters of tofu liquid waste and distilled water mixture is put into the reservoir. The tofu liquid waste is pumped into the reactor using a diaphragm pump. Ozone with dosage $155 \mathrm{mg} / \mathrm{h}$ is injected into the system by connecting the hose from Ozonator to the reactor using venture injector. One hundred grams of GAC is placed in the inside of the reactor. This method is operated for $2 \mathrm{~h}$, and samples are taken at minute 15 , $30,45,60,90$, and 120.

\section{COD concentration test}

The number of COD in the sample is obtained using a spectrophotometer. Two and half milliliters of sample is added to the COD reagent, then heated until it reaches a temperature of $150^{\circ} \mathrm{C}$. Samples are heated for $2 \mathrm{~h}$. Then, the number of COD of the sample is read using spectrophotometer at a wavelength of $600 \mathrm{~nm}$.

\section{TSS concentration test}

The number of TSS in the sample is obtained using colorimeter $\mathrm{HACH}$. Samples are put inside the colorimeter, and then set the program of the colorimeter to Suspended Solid Reading.

\section{RESULT AND DISCUSSION}

Quantification of hydroxyl radical is done to know the amount of hydroxyl radical produced from ozonation 


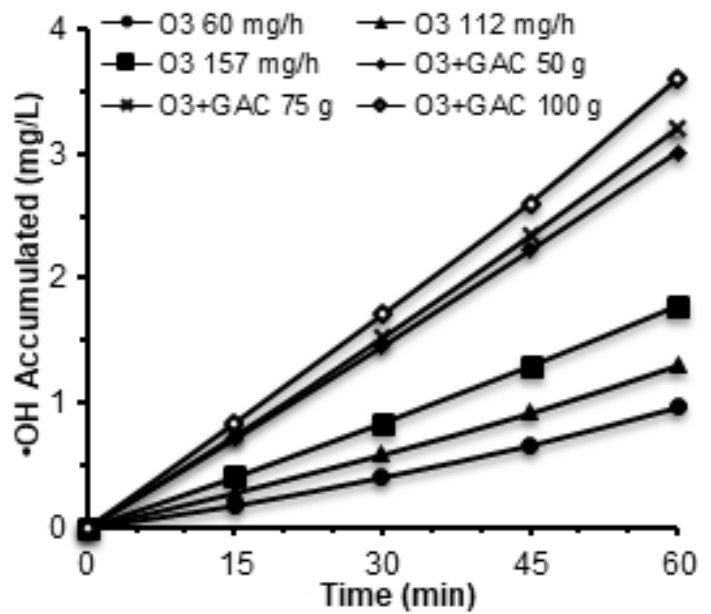

Fig 2. Effect of ozone dosage and amount of GAC on hydroxyl radical production (flow rate $=1.5 \mathrm{LPM}$ )

and combination of ozonation and adsorption method. Hydroxyl radical is a better oxidation agent than ozone itself, therefore it is useful to know how many hydroxyls radical being produced. The addition of GAC and ozone shows a synergic result, yielding higher hydroxyl radical quantification number than using ozone itself, 69 to $101 \%$ depending on the weight of GAC used. This is the result of the reaction between ozone and the active site of GAC. The result can be seen in Fig. 2 .

\section{BET Autosorb Analysis of GAC}

Before being activated, the BET surface area of GAC used is $645.5178 \mathrm{~m}^{2} / \mathrm{g}$. After activated, the BET surface area of GAC used is $712.1729 \mathrm{~m}^{2} / \mathrm{g}$. Increase in the surface area showed that dirt and water content have been removed by the activation process.

\section{Ozonation Method for Tofu Wastewater Treatment}

For the ozonation method, a variation of ozone dosage injected into the system is done using three dosages of ozone: 62, 111, and $155 \mathrm{mg} / \mathrm{h}$. These dosages are based on ozone gas production test conducted by the researcher using iodometric titration approach. The ozone gas production of each number of Ozonator used in this experiment is shown in Table 1.

The more ozone introduced to the system, the number of total COD removed from the system is higher. More ozone introduced into the system means more possibility of hydroxyl radical production. $62 \mathrm{mg} / \mathrm{h}$ of ozone was able to remove $14.11 \mathrm{mg} / \mathrm{L}, 111 \mathrm{mg} / \mathrm{h}$ of ozone was able to remove $45 \mathrm{mg} / \mathrm{L}$, and $155 \mathrm{mg} / \mathrm{h}$ of ozone was able to remove $54.36 \mathrm{mg} / \mathrm{L}$ COD. The graph can be seen in Fig. 3. Ozone breaks down the molecule chain of organic components in the tofu liquid wastewater, resulted

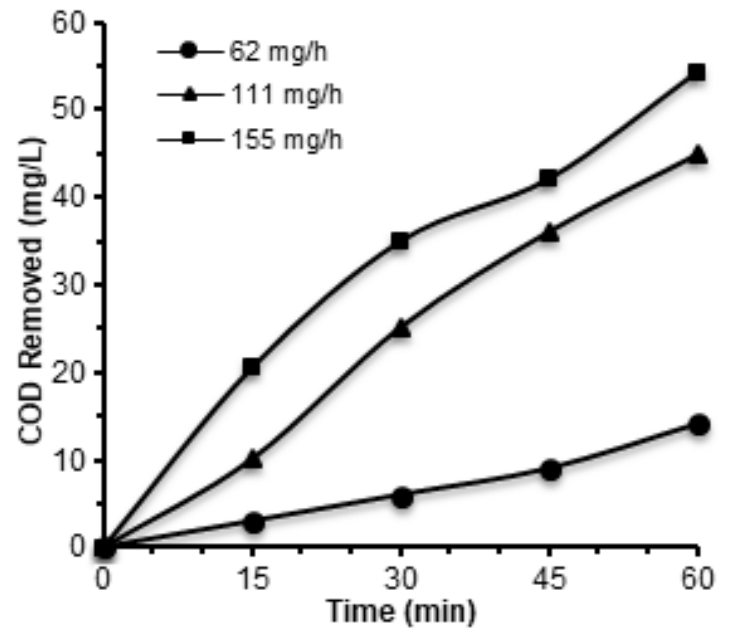

Fig 3. Effect of ozone dosage on COD removal (flow rate $=1.5$ LPM)

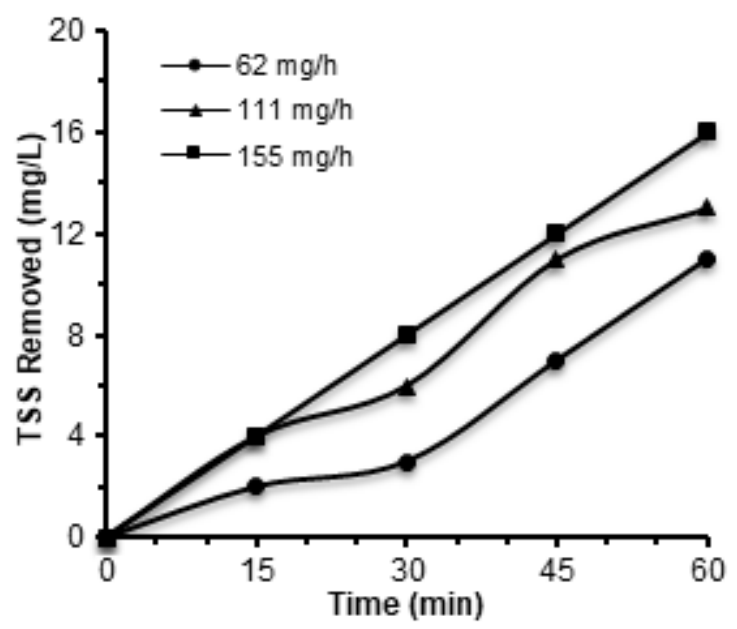

Fig 4. Effect of ozone dosage on TSS removal (flow rate $=1.5 \mathrm{LPM}$ )

Table 1. Ozone dosage based on number of ozonator used

\begin{tabular}{ccc}
\hline No & Number of ozonator & Ozone dosage $(\mathrm{mg} / \mathrm{h})$ \\
\hline 1 & 1 & 62 \\
2 & 2 & 111 \\
3 & 3 & 155 \\
\hline
\end{tabular}

in lower COD number.

Higher dosage of ozone removed more TSS from the system. Overall, ozone did not remove much TSS because ozone only creates flocculation of the solid in the system, so the solids are not completely removed. In addition, this may be the effect of the initial condition of the system that did not have too high TSS concentration. The result of using ozone for this experiment shows TSS removal for $62 \mathrm{mg} / \mathrm{h}$ of ozone is $11 \mathrm{mg} / \mathrm{L}, 111 \mathrm{mg} / \mathrm{h}$ of ozone removed $13 \mathrm{mg} / \mathrm{L}$, and $155 \mathrm{mg} / \mathrm{h}$ of ozone removed 


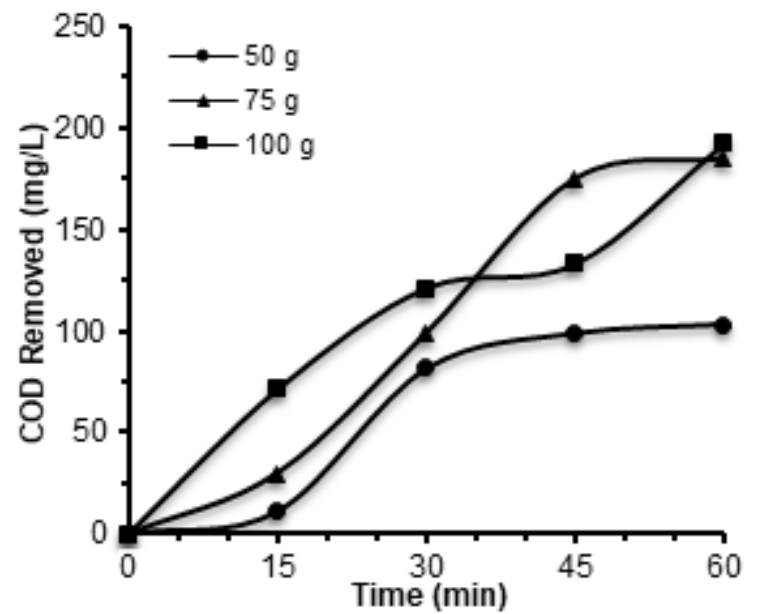

Fig 5. Effect of GAC amount on COD removal (flow rate $=1.5$ LPM)

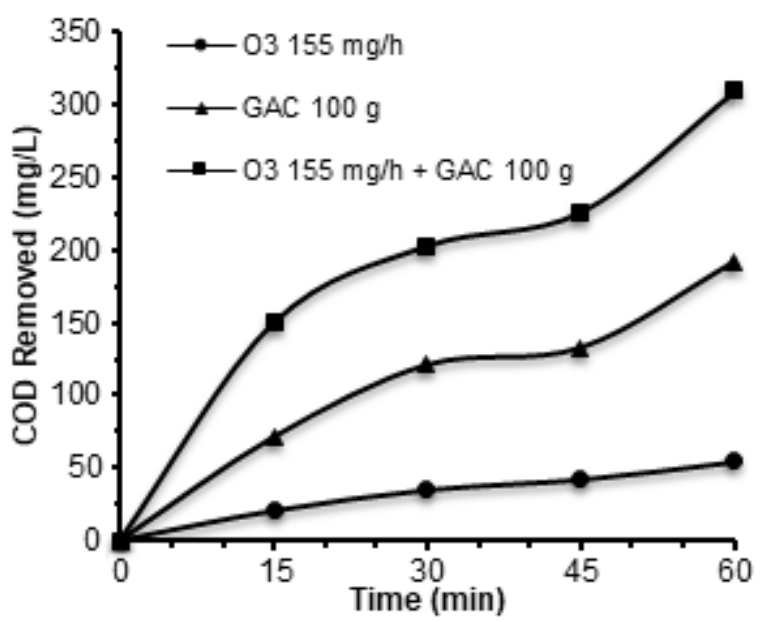

Fig 7. Comparison between single ozonation, single adsorption, and the combination of ozonation and adsorption on COD removal (flow rate $=1.5$ LPM)

$16 \mathrm{mg} / \mathrm{L}$ of TSS. The graph of TSS elimination by ozonation can be seen in Fig. 4.

\section{Adsorption Method for Tofu Wastewater Treatment}

For the adsorption method, a variation of the dry weight of GAC is carried out using 50,75 , and $100 \mathrm{~g}$ of GAC inside the reactor. The more GAC put inside the reactor, the number of COD removed is higher. Adsorption of pollutant in the wastewater is caused by capillary force with GAC pores that is higher than pollutant with the solute itself, hence organic molecules are attracted inside the pores of GAC. However, when the saturation point is reached, COD removal using GAC is no longer effective. For $50 \mathrm{~g}$ of GAC used, it can be seen that after $30 \mathrm{~min}$, the GAC has reached its saturation point and the adsorption rate becomes slower. Fifty grams of

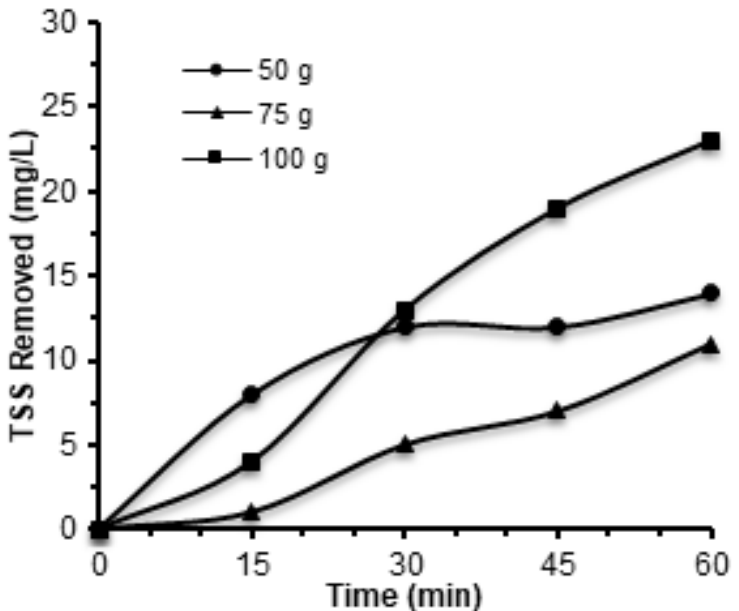

Fig 6. Effect of GAC amount on TSS removal (flow rate $=1.5 \mathrm{LPM})$

GAC removed $103.18 \mathrm{mg} / \mathrm{L}$ of COD, $75 \mathrm{~g}$ of GAC removed $185 \mathrm{mg} / \mathrm{L}$ of $\mathrm{COD}$, and $100 \mathrm{~g}$ of GAC removed $192.12 \mathrm{mg} / \mathrm{L}$ of COD. The graph of COD elimination using an adsorption method can be seen in Fig. 5 .

The longer period of operation, the higher is the TSS removed from the system. Longer operation time provides better diffusion and attachment of adsorbent into the pores of GAC. Fifty grams of GAC removed 14 $\mathrm{mg} / \mathrm{L}$ of TSS, $75 \mathrm{~g}$ of GAC removed $11 \mathrm{mg} / \mathrm{L}$ of TSS, and $100 \mathrm{~g}$ of GAC removed $768.48 \mathrm{mg} / \mathrm{L}$ of TSS. The addition of more GAC did not result in the higher removal of TSS. Inconsistency shown can be the result of weak van der Walls force between the pollutant and activated carbon. The graph of TSS removal using an adsorption method can be seen in Fig. 6 .

\section{Combination of Ozonation and Adsorption Method for Tofu Wastewater Treatment}

Adsorption is better than ozonation method to remove COD from tofu liquid wastewater. This can be the effect of tofu liquid wastewater's naturally acidic $\mathrm{pH}$. When the $\mathrm{pH}$ is low, the more dominant oxidizing agent is ozone, which its reduction potential is lower than $\cdot \mathrm{OH}$. To increase the effectiveness of tofu liquid wastewater degradation process, the combination of both two methods is being done. The result was the combination of ozonation and adsorption removed COD of tofu liquid wastewater the most. After $1 \mathrm{~h}$, a combination of ozonation and adsorption was able to remove 309.92 $\mathrm{mg} / \mathrm{L}$ of COD, and $2 \mathrm{~h}$ of operation removed $377.12 \mathrm{mg} / \mathrm{L}$ of $C O D$ in total. The graph of COD elimination using ozonation and adsorption method and comparison between the three methods can be seen in Fig. 7 .

Single ozonation method resulted in the least COD elimination. This is because the molecule of proteins 


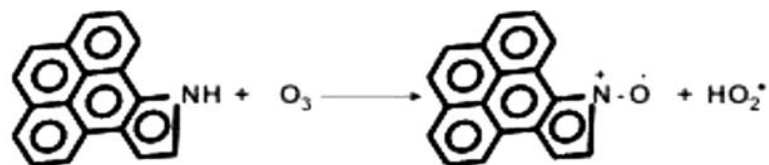

Fig 8. Pyrrole group reaction with ozone [16]

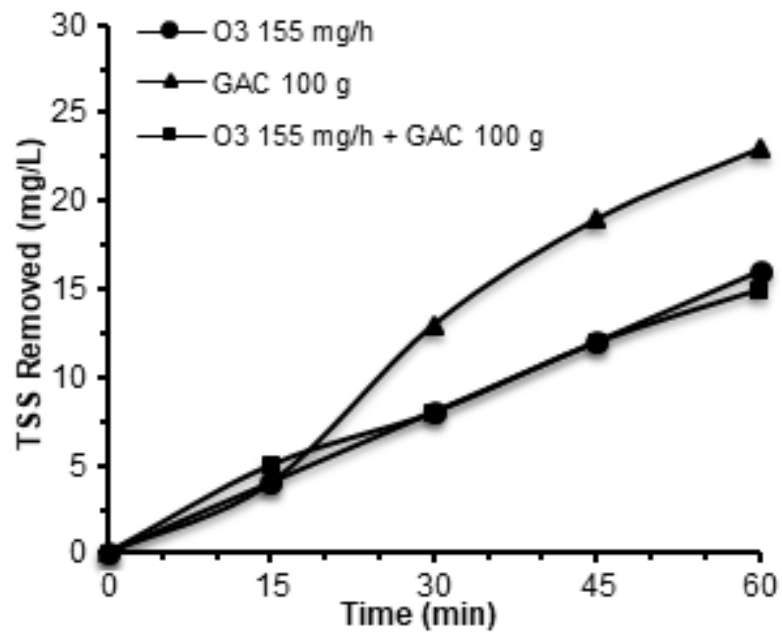

Fig 9. Comparison between single ozonation, single adsorption, and the combination of ozonation and adsorption on TSS removal (flow rate $=1.5$ LPM)

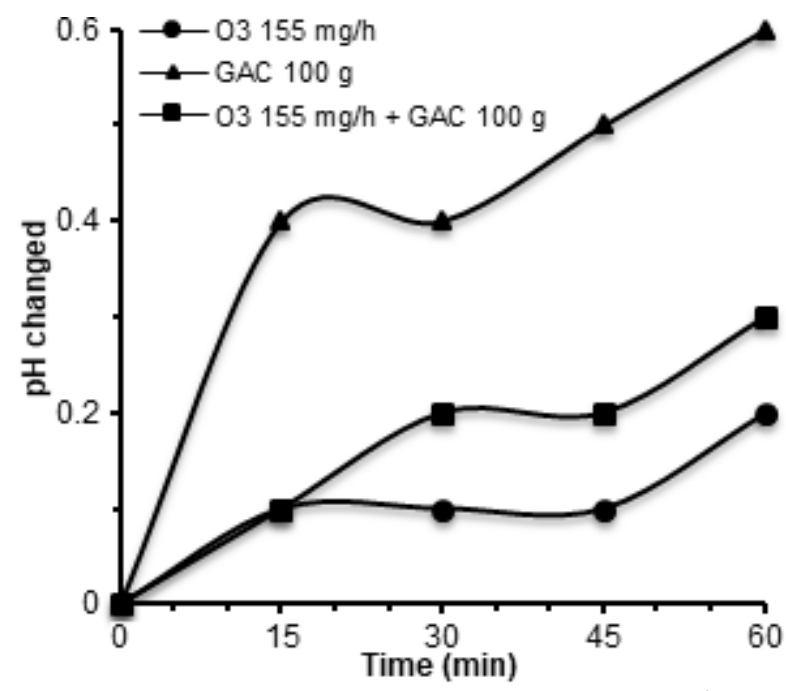

Fig 10. The $\mathrm{pH}$ change during the process for three different methods (flow rate $=1.5$ LPM)

contained in the tofu liquid wastewater is very long, therefore it is hard for the ozone and hydroxyl radical to completely broke the long molecule chain. The addition of GAC not only increased $\cdot \mathrm{OH}$ production but also provide room for adsorption inside the pores of the activated carbon. Ozone reacts with the pyrrole group at graphene layer of $\mathrm{GAC}$ resulting $\mathrm{N}$-oxide and hydroperoxide radical, illustrated in Fig. 8.
The generation of hydroperoxide radical is the factor that increases the production of hydroxyl radical, according to the ozonation reaction below [16].

$\mathrm{HO}_{2} \bullet \leftrightarrow \mathrm{O}_{2} \cdot-+\mathrm{H}+$

$\mathrm{O}_{3}+\mathrm{O}_{2} \cdot-\rightarrow \mathrm{O}_{3} \cdot-+\mathrm{O}_{2}$

$\mathrm{O}_{3} \cdot+\mathrm{H}+\rightarrow \mathrm{HO}_{3} \cdot$

$\mathrm{HO}_{3} \cdot \rightarrow \cdot \mathrm{OH}+\mathrm{O}_{2}$

Compared with adsorption and ozonation method, for over $1 \mathrm{~h}$ operation time adsorption period was better than the combination of ozonation and adsorption. However, with the addition of ozone, TSS removal is higher after $2 \mathrm{~h}$ of operation. After $1 \mathrm{hr}$, a combination of ozonation and adsorption was able to remove $15 \mathrm{mg} / \mathrm{L}$ of TSS, and $2 \mathrm{~h}$ of operation removed $26 \mathrm{mg} / \mathrm{L}$ of TSS. The graph of TSS elimination using ozonation and adsorption method and comparison between the three methods can be seen in Fig. 9 .

With initial concentrations of COD and TSS in the range of $780-850$ and $200-220 \mathrm{mg} / \mathrm{L}$ respectively, the COD removal that can be achieved by the combined method (final concentration of $377 \mathrm{mg} / \mathrm{L}$ ) is still higher than the threshold limit from Indonesian Government which are 300 and $200 \mathrm{mg} / \mathrm{L}$ for COD, and TSS respectively. This is because the organic compounds contained in wastewater are macromolecule compounds in the form of protein. Thus, it needs more ozone to remove them. Meanwhile, the ozonators used in this study are household small-scale commercial ozonators with low ozone production capacity. However, the final concentration of TSS has met the quality standard which is below the threshold limit.

\section{Effect of Treatment Method on the pH Change}

The presence of GAC results in a higher $\mathrm{pH}$ increase than the single ozonation method. This occurs due to the absorption of hydrogen ions by the activated carbon, thereby decreasing the amount of hydrogen ions in the waste solution and causing an increase in the $\mathrm{pH}$ value [17]. In the combination method of ozonation and adsorption, the $\mathrm{pH}$ increment is not as large as the adsorption method. This is due to the presence of acidic intermediate compounds which are formed from ozone reaction with organic compounds. Therefore, the presence of adsorbent which tends to increase the $\mathrm{pH}$ by adsorbing hydrogen ions can be offset by the presence of these intermediate compounds. The $\mathrm{pH}$ changed during the process for three kinds of the method used can be seen in Fig. 10.

\section{CONCLUSION}

Ozonation and adsorption using GAC were able to remove COD and TSS of tofu liquid wastewater better than ozonation or adsorption alone because the addition 
of GAC was able to become adsorbent and increased the production of hydroxyl radical. The more ozone and the more quantity of GAC used, the higher the number of hydroxyl radicals formed. Addition of GAC in the ozonation process results in more than $100 \%$ increase in hydroxyl radical production. Ozonation alone did not give good result compared with adsorption or combination method due to a long-chained molecule inside tofu liquid wastewater. Highest COD and TSS removal were found using the combination of both method, with total COD removed $377.12 \mathrm{mg} / \mathrm{L}$ and TSS removed $26 \mathrm{mg} / \mathrm{L}$. To use this proposed technique in the future, further study should be done on optimizing the degradation result. It is also suggested to do further testing like LC-MS to analyze the production of an intermediate compound to see the effectiveness of the proposed method.

\section{ACKNOWLEDGEMENT}

The authors acknowledge Universitas Indonesia and PITTA 2017 program No. 775/UN2.R3.1/HKP.05.00/ 2017 for the financial support. We also thank Process Intensification Laboratory Chemical Engineering Department Universitas Indonesia, FMIPA Universitas Negeri Jakarta for the instruments to analyze this experiment.

\section{REFERENCES}

[1] Kaswinarni, F., 2007, Kajian teknis pengolahan limbah cair padat dan cair industri tahu, studi kasus industri tahu sandang Semarang, sederhana Kendal dan gagak sipat Boyolali, Thesis, Universitas Diponegoro, Semarang.

[2] Pohan, 2008, Pengolahan limbah cair industri tahu dengan proses biofilter aerobik, Thesis, Universitas Sumatera Utara, Medan.

[3] Abineri, H.S., Sato, A., and Utomo, P., 2015, Pengolahan limbah tahu secara anaerobik-aerobik kontinu, Seminar Nasional Sains dan Teknologi Terapan III 2015, Institut Teknologi Adhi Tama Surabaya.

[4] Peraturan Menteri Lingkungan Hidup Republik Indonesia Nomor 5 Tahun 2014 Tentang Baku Mutu Air Limbah.

[5] Langlais, B., Reckhow, D.A., and Brink, D.R., 1991, Ozone in Water Treatment: Application and Engineering: Cooperative Research Report, American Water Works Association and Compagnie Generale des Eaux, Denver, CO.

[6] Fessenden, R.J., and Fessenden, J.S., 1990, Kimia Organik, $1^{\text {st }}$ ed., Aloysius (Trans.), Erlangga, Jakarta.
[7] Wu, J., 2004, Modeling Adsorption of Organic Compounds on Activated Carbon, Dissertation, Umea University, Sweden.

[8] Dobre, T., Pârvulescu, O.C., lavorschi, G., Stroescu, M., and Stoica, A., 2014, Volatile organic compounds removal from gas streams by adsorption onto activated carbon, Ind. Eng. Chem. Res., 53 (9), 3622-3628.

[9] Goi, A., 2005, Advanced Oxidation Processes for Water Purification and Soil Remediation, Thesis, Tallinn University of Technology, Estonia.

[10] Ghuge, S.P., and Saroha, A.K., 2018, Catalytic ozonation for the treatment of synthetic and industrial effluents - Application of mesoporous materials: A review, J. Environ. Manage., 211, 83102.

[11] Hadavifar, M., Younesi, H., Zinatizadeh, A.A., Mahdad, F., Li, Q., and Ghasemi, Z., 2016, Application of integrated ozone and granular activated carbon for decolorization and chemical oxygen demand reduction of vinasse from alcohol distilleries, J. Environ. Manage., 170, 28-36.

[12] Gümüș, D., and Akbal, F., 2017, A comparative study of ozonation, iron coated zeolite catalyzed ozonation and granular activated carbon catalyzed ozonation of humic acid, Chemosphere, 174, 218231.

[13] Karamah, E.F., Leonita, S., and Bismo, S., 2018, Phenols removal using ozonation-adsorption with granular activated carbon (GAC) in rotating packed bed reactor, IOP Conf. Ser. Mater. Sci. Eng., 299, 012094.

[14] Rozas, O., Baeza, C., Nunez, K., Rossner, A., Urrutia, R., and Mansilla H.D., 2017, Organic micropollutants (OMPs) oxidation by ozone: Effect of activated carbon on toxicity abatement, Sci. Total Environ., 590-591, 430-439.

[15] Suryana, M.D., 2016, Penyisihan Sianida dan Chemical Oxygen Demand dari Limbah Cair Industri Tepung Tapioka dengan Teknik Ozonasi Adsorpsi Menggunakan Granular Activated Carbon, Thesis, Universitas Indonesia, Depok.

[16] Sanchez-Polo, M., von Gunten, U., and RiveraUtrilla, J., 2005, Efficiency of activated carbon to transform ozone into $\cdot \mathrm{OH}$ radicals: Influence of operational parameters, Water Res., 39 (14), 31893198.

[17] Laras, N.S., Yuliani, and Fitrihidajati H., 2015, Pemanfaatan arang aktif limbah kulit kacang kedelai (Glycine max) dalam meningkatkan kualitas limbah cair tahu, LenteraBio, 4 (1), 72-76. 